\title{
SPECYFIKA BADAŃ POLITOLOGICZNYCH NAD MYŚLĄ POLITYCZNĄ W ZAKRESIE BEZPIECZEŃSTWA ENERGETYCZNEGO PAŃSTWA
}

\begin{abstract}
Zapewnienie bezpieczeństwa jest jednym z najważniejszych zadań kształtujących politykę każdego państwa. Znaczenie tego zagadnienia jest uwarunkowane czynnikami o charakterze wewnętrznym (rozwój krajowych systemów energetycznych), jak i zewnętrznym (oddziaływanie na impulsy ze strony innych państw). Współcześnie z uwagi na ewolucję środowiska międzynarodowego rośnie znaczenie pozamilitarnych wymiarów bezpieczeństwa. Celem artykułu było określenie istoty badań politologicznych nad myślą polityczną w zakresie bezpieczeństwa energetycznego państwa. Problematyka ta jest istotną kategorią badawczą, która dotychczas była analizowana w ograniczonym zakresie. W artykule zaprezentowano sposób definiowania terminu bezpieczeństwo energetyczne przez zwolenników dwóch współcześnie dominujących nurtów badawczych w stosunkach międzynarodowych (realizm, liberalizm). Jednocześnie autor zaproponował ze-staw dziewięciu zjawisk i wydarzeń, które powinny być przedmiotem badań naukowców zajmujących się myślą polityczną w zakresie bezpieczeństwa energetycznego państwa. Po pierwsze - procesy gospodarcze, w tym kwestia własności w sektorach energetycznych. Po drugie - koncepcje gospodarcze, w których za-warta jest wizja pożądanej struktury sektorów gospodarczych. Po trzecie - realizacja projektów o charakterze krajowym, jak i międzynarodowym zwiększających bezpieczeństwo energetyczne państwa. Po czwarte stosunek do zagospodarowania krajowych złóż surowców energetycznych. Po piąte akcesja do organizacji międzynarodowych o charakterze energetycznym. Po szóste ekspansja kapitałowa przedsiębiorstw energetycznych. Po siódme - stosunek do inwestycji międzynarodowych mogących negatywnie wpłynąć na bezpieczeństwo energetyczne państwa. Po ósme - projekty polityczne dotyczące zapewnienia bezpieczeństwa energetycznego państwa. Po dziewiąte - współpraca energetyczna z konkretnymi państwami oraz ocena tej kooperacji.
\end{abstract}

Słowa kluczowe: realizm, liberalizm, myśl polityczna, bezpieczeństwo energetyczne.

\section{WPROWADZENIE}

Zapewnienie bezpieczeństwa jest jednym z najważniejszych zadań kształtujących politykę każdego państwa. Ewolucja środowiska międzynarodowego spowodowała zmianę warunków funkcjonowania państw, co wpłynęło jednocześnie na reorientację natury zagrożeń, które współcześnie nie obejmują wyłącznie charakteru militarnego. W konsekwencji rośnie znaczenie innych wymiarów bezpieczeństwa. Przyjmując, że decyzje polityczne są determinowane przez czynniki ekonomiczne oraz wywołują skutki w życiu

\footnotetext{
${ }^{1}$ Dr Michał Paszkowski, Zakład Teorii Polityki i Metodologii Politologii, Wydział Politologii, Uniwersytet Marii Curie-Skłodowskiej w Lublinie, e-mail: michal.paszkowski@interia.pl
} 
gospodarczym², należy uznać zasadność prowadzenia badań nad myślą polityczną w wymiarze ekonomicznym, w tym także energetycznym.

$\mathrm{W}$ aspekcie politologicznym analiza bezpieczeństwa energetycznego jako kategorii badawczej jest niezwykle ważna, ponieważ pozwala wyjaśnić genezę zjawisk politycznych oraz uchwycić ewolucję przemian gospodarczych. Dla badań myśli politycznej w zakresie bezpieczeństwa energetycznego ważne jest określenie sposobu definiowania terminu „bezpieczeństwo energetyczne” przez zwolenników dwóch dominujących nurtów badawczych w stosunkach międzynarodowych (liberalizm, realizm).

Celem artykułu jest określenie istoty badań politologicznych nad myślą polityczną w zakresie bezpieczeństwa energetycznego państwa. W efekcie zaproponowano zestaw zjawisk i wydarzeń, które powinny być przedmiotem badań naukowców zajmujących się myślą polityczną w zakresie bezpieczeństwa energetycznego państwa. Analiza politologiczna tego typu zagadnień pozwoli z jednej strony na systematyzację badań (aspekt metodologiczny), $\mathrm{z}$ drugiej zaś umożliwi określenie postulowanej przez poszczególne podmioty polityczne wizji kształtu gospodarki oraz środowiska międzynarodowego (aspekt poznawczy).

\section{BEZPIECZEŃSTWO ENERGETYCZNE JAKO KATEGORIA BADAWCZA}

Bezpieczeństwo jest jedną $\mathrm{z}$ najważniejszych wartości, które państwo stara się zapewnić (chronić) ${ }^{3}$. Stanowi pierwszy i podstawowy cel polityki, a państwa podejmują odpowiednie przedsięwzięcia w celu jego zapewnienia ${ }^{4}$. Współcześnie można zauważyć zmianę myślenia i definiowania terminu „bezpieczeństwo”. Twórcy definicji zaczynają poszerzać zakres zarówno podmiotowy, jak i przedmiotowy tego terminu, traktując go wszechstronnie. W okresie ,zimnej wojny” punktem odniesienia dla analizy środowiska międzynarodowego był wymiar wojskowy i związany z nim wyścig zbrojeń. Ewolucja środowiska międzynarodowego spowodowała konieczność dokonania

\footnotetext{
${ }^{2}$ W. Paruch, Kategorie ekonomiczne a zakres pojęcia myśl polityczna - refleksje metodologiczne, [w:] Idee, państwo, ludowcy. Księga jubileuszowa z okazji 70. rocznicy urodzin profesora Jana Jachymka, red. E. Maj, S. Michałowski, A. Wójcik, Lublin 2009, s. 41.

${ }^{3} \mathrm{Na}$ temat sposobu rozumienia terminu bezpieczeństwo zob. K. Żukrowska, Pojęcie bezpieczeństwa i jego ewolucja, [w:] Bezpieczeństwo międzynarodowe. Teoria i praktyka, red. M. Grącik, K. Żukrowska, Warszawa 2006, s. 21; J. Symonides, Problem pokoju $i$ bezpieczeństwa międzynarodowego we wspótczesnym świecie, [w:] Wychowanie dla pokoju, red. B. Suchodolski, Wrocław-Warszawa-Kraków-Gdańsk-Łódź 1983, s. 45; idem, Pozimnowojenny paradygmat bezpieczeństwa międzynarodowego, [w:] Bezpieczeństwo międzynarodowe po zimnej wojnie, red. $\mathrm{R}$. Zięba, Warszawa 2008, s. 16; idem, Kategoria bezpieczeństwa w nauce o stosunkach międzynarodowych, [w:] Bezpieczeństwo narodowe i międzynarodowe u schytku XX wieku, red. D.B. Bobrow, E. Haliżak, R. Zięba, Warszawa 1997, s. 5; idem, Pojęcie i istota bezpieczeństwa państwa w stosunkach międzynarodowych, „Sprawy Międzynarodowe” 1989/10, s. 50-52; J. Stańczyk, Współczesne pojmowanie bezpieczeństwa, Warszawa 1996, s. 15-48.

${ }^{4} \mathrm{R}$. Zięba, Cele polityki zagranicznej państwa, [w:] Wstęp do teorii polityki zagranicznej państwa, red. R. Zięba, Toruń 2004, s. 37; R. Kuźniar, Bezpieczeństwo w stosunkach międzynarodowych, [w:] Stosunki międzynarodowe. Geneza - Struktura - Dynamika, red. E. Haliżak, R. Kuźniar, Warszawa 2006, s. 143.
} 
przewartościowania i poszerzenia zakresu tego pojęcia ${ }^{5}$. Współcześnie - oprócz zatem tradycyjnie postrzeganego wymiaru militarnego bezpieczeństwa - jest zasadne prowadzenie badań na temat pozamilitarnych wymiarów bezpieczeństwa (bezpieczeństwo polityczne, ekonomiczne, ekologiczne oraz społeczne i kulturowe).

W celu zrozumienia terminu bezpieczeństwo energetyczne niezbędne jest określenie jego istoty, w tym rozróżnienie sposobu definiowania tego pojęcia przez dwa współcześnie dominujące nurty badawcze w stosunkach międzynarodowych, czyli realizmu oraz liberalizmu ${ }^{6}$. Obie szkoły teoretyczne zdecydowanie odmiennie traktują to zagadnienie. Dla realistów jedynym podmiotem stosunków międzynarodowych jest państwo, które dąży do wzmocnienia suwerenności rozumianej jako niezależność od czynników zewnętrznych. Bezpieczeństwo w ramach tej szkoły teoretycznej jest zatem państwowocentryczne, to znaczy państwo jest jedynym podmiotem, którego bezpieczeństwo ma być zapewnione ${ }^{7}$. Nadrzędnym celem państwa jest zatem zapewnienie bezpieczeństwa $\mathrm{w}$ sensie egzystencjalnym (przetrwanie). Odnosząc takie podejście do bezpieczeństwa energetycznego, należy wskazać, że podmiotem analizy w odniesieniu do paradygmatu realistycznego jest państwo. Dlatego też dla zwolenników tego nurtu, przy uwzględnieniu silnie eksponowanego interesu państwa, istotne jest zagwarantowanie bezpieczeństwa energetycznego poprzez zapewnienie stabilnych dostaw surowców, z uwzględnieniem tras i kierunków ich importu. Państwo nie mające wystarczających zasobów surowców energetycznych mogących zapewnić niezależność energetyczną może zostać wzmocnione jedynie poprzez politykę zróżnicowania importu (dywersyfikacja).

$\mathrm{W}$ odniesieniu do nurtu liberalnego w stosunkach międzynarodowych jego zwolennicy odmiennie traktują problem bezpieczeństwa ${ }^{8}$. Ostatecznym celem państwa jest bowiem dobrobyt i pomyślność społeczeństwa, dlatego decydujące są przede wszystkim kwestie ekonomiczne i społeczne. Wzrost współzależności jest najlepszym gwarantem pokoju, ponieważ sprawia, że wykorzystywanie siły w stosunkach międzynarodowych (wojna) niesie za sobą zaburzenia funkcjonującego systemu. Zgodnie z tym stanowiskiem rozwój gospodarczy służy społeczności międzynarodowej, dzięki niemu bowiem maleje groźba wybuchu konfliktu zbrojnego ${ }^{9}$. Odnosząc tak rozumiane podejście do bezpieczeństwa energetycznego, należy wskazać, że zwolennicy orientacji liberalnej za konieczne uznają zagwarantowanie obywatelom dostaw surowców energetycznych w odpowiednich cenach. W ich ocenie celem państwa powinny być zapewnienie rozwoju i ochrona indywidualnych praw jednostek ludzkich. W tym kontekście można wskazać, że zwolennicy tego podejścia $\mathrm{w}$ ograniczonym zakresie zwracają uwagę na źródło pochodzenia surowców energetycznych.

\footnotetext{
${ }^{5}$ B. Buzan, People, States and Fear. An Agenda for International Security Studies in the Post-Cold War Era, London 1991, s. 19-20.

${ }^{6} \mathrm{Na}$ temat nurtu realistycznego zob. S. Burchill, Realizm i neoliberalizm, [w:] Teorie stosunków międzynarodowych, red. S. Burchill i in., Warszawa 2006, s. 97-119; J. Czaputowicz, Teorie stosunków międzynarodowych. Krytyka i systematyzacja, Warszawa 2007, s. 58-102; R. Jackson, G. Sørensen, Wprowadzanie do stosunków międzynarodowych. Teorie i kierunki badawcze, Kraków 2006, s. 69-109.

${ }^{7}$ J. Czaputowicz, Bezpieczeństwo w teoriach stosunków międzynarodowych, [w:] Bezpieczeństwo międzynarodowe. Przegląd aktualnego stanu, red. K. Żukrowska, Warszawa 2011, s. 70.

$8 \mathrm{Na}$ temat nurtu liberalnego zob. S. Burchill, Liberalizm, [w:] Teorie stosunków międzynarodowych ..., s. 46-92; R. Jackson, G. Sørensen, op. cit., s. 111-146.

${ }^{9}$ J. Czaputowicz, Bezpieczeństwo w teoriach ..., s. 82.
} 
Termin „bezpieczeństwo energetyczne” jest jedną z kategorii szeroko analizowanego bezpieczeństwa i w zależności od autorów zajmujących się tą problematyką, różnie jest definiowane, co nie pomaga jednoznacznie określić jego zakresu i znaczenia. Współcześnie termin bezpieczeństwo energetyczne badacze formułują przede wszystkim w oparciu na liberalnym nurcie badawczym w stosunkach międzynarodowych ${ }^{10}$. Dla zwolenników liberalnej orientacji metodologicznej bezpieczeństwo energetyczne jest rozumiane między innymi jako ,stan gospodarki umożliwiający pokrycie bieżącego i perspektywicznego zapotrzebowania odbiorców na paliwa i energię w sposób technicznie i ekonomicznie uzasadniony, przy zachowaniu wymagań ochrony środowiska"11. Według tej definicji podmiotem ochrony jest obywatel, ponieważ oprócz potrzeby zapewnienia dostaw energii podkreślona została kwestia ceny energii, która powinna być ekonomicznie uzasadniona.

Natomiast przyjmując, że dla zwolenników realistycznej orientacji metodologicznej podmiotem chronionym jest państwo, nie wnikając w złożoność pojęcia bezpieczeństwo energetyczne, można stwierdzić, że oznacza nieprzerwany dostęp do źródeł energii w każdym czasie, w różnych formach i ilości umożliwiającej prawidłowe funkcjonowanie państwa. Zaproponowana definicja jest charakterystyczna dla nurtu realistycznego i wskazuje na bardzo ważny aspekt bezpieczeństwa, czyli dostęp do surowców i nośników energii niezależnie od sytuacji wewnętrznej i międzynarodowej oraz oferowanej ceny. Podmiotem ochrony w tym wypadku jest państwo.

Sposób rozumienia terminu ,bezpieczeństwo energetyczne” stanowi podstawę do dokonania oceny formułowanych poglądów i podejmowanych przez podmioty polityczne działań. W wypadku ujęcia liberalnego brak ekonomicznego uzasadnienia dla projektów energetycznych powodowałby, że tego typu inwestycje nie byłyby realizowane. Natomiast w odniesieniu do ujęcia realistycznego kluczową przesłanką realizacji konkretnych przedsięwzięć energetycznych jest potrzeba zapewnienia bezpieczeństwa energetycznego. Kwestia ekonomicznej opłacalności inwestycji odgrywa w tym wypadku rolę drugorzędną. Niewątpliwie rozstrzygnięcia definicyjne pełnią ważną funkcję, ponieważ na tej podstawie oraz w oparciu na powszechnie dostępnej, specjalistycznej wiedzy $\mathrm{z}$ zakresu politologii i stosunków międzynarodowych badacze powinni dokonywać oceny koncepcji oraz rzeczywistych działań podejmowanych przez podmioty polityczne.

Współcześnie surowce energetyczne stają się środkiem realizacji celów politycznych, czego najlepszym przykładem były: dwie wojny w Zatoce Perskiej (1990-1991, 2003), konflikty gazowe białorusko-rosyjski (2005) i ukraińsko-rosyjskie (2006, 2009). Niewątpliwie wspomniane wydarzenia dowiodły, jak wielką rolę odgrywają nośniki energii. Dlatego też w ocenie autora problem bezpieczeństwa należy rozpatrywać zgodnie

10 W dokumencie Polityka energetyczna Polski do 2025 roku termin „bezpieczeństwo energetyczne” zdefiniowano jako „to stan gospodarki umożliwiający pokrycie bieżącego i perspektywicznego zapotrzebowania odbiorców na paliwa i energii, w sposób technicznie i ekonomicznie uzasadniony, przy minimalizacji negatywnego oddziaływania sektora energii na środowisko i warunki życia społeczeństwa. Archiwum Autora, Polityka bezpieczeństwa energetycznego Polski do 2025 roku. Dokument przyjęty przez Radę Ministrów w dniu 4 stycznia 2005 roku.

${ }^{11}$ Dziennik Ustaw 1997, nr 54, poz. 348, ze zm., Ustawa z 10 kwietnia 1997 roku Prawo energetyczne. 
z paradygmatem realistycznym, uprawnione jest bowiem twierdzenie, że współcześnie gospodarka jest jedynie narzędziem w polityce zagranicznej państw (w stosunkach międzynarodowych dominuje tendencja ścierania się wpływów ekonomicznych, w tym także energetycznych).

\section{ZAKRES RZECZOWY MYŚLI POLITYCZNEJ W ASPEKCIE ENERGETYCZNYM}

Zapewnienie bezpieczeństwa energetycznego wymusza prowadzenie aktywnej polityki oraz niwelowanie negatywnych zjawisk, wpływających na rozwój oraz funkcjonowanie obywateli, działających na terytorium państw podmiotów gospodarczych oraz gospodarki narodowej jako całości. Badania myśli politycznej w aspekcie bezpieczeństwa energetycznego państwa wymagają określenia zagadnień, które powinny być przedmiotem zainteresowań naukowców. Ich zdefiniowanie wynika z założenia, że nie wszystkie zjawiska i wydarzania odnoszące się do kwestii gospodarczych powinny znaleźć się w centrum uwagi politologów.

Prawidłowe uszczegółowienie zakresu rzeczowego badań nad myślą polityczną w aspekcie energetycznym jest niezwykle istotne. Pozwala bowiem na określenie obszaru badawczego, a także na wskazanie zagadnień, które nie mieszczą się w tej kategorii badawczej $^{12}$. Dodatkowo współcześnie wielu badaczy analizuje kwestie energetyczne jedynie przez pryzmat opisu działań podejmowanych przez rząd w kierunku zapewnienia bezpieczeństwa energetycznego ${ }^{13}$.

Aktywność podmiotów politycznych (m.in. polityków, partii politycznych) w sferze publicznej pozwala, na podstawie badań nad myślą polityczną z jednej strony opisać postulowaną wizję gospodarczą danego podmiotu, z drugiej zaś dokonać jej oceny pod względem zasadności i skuteczności aktywności politycznej. Podejmowane przez poszczególnych uczestników życia politycznego decyzje wpływają na proces decyzyjny oraz kształtują życie gospodarcze w danym państwie. W tym kontekście należy wskazać, że formułowane poglądy i decyzje odnoszą się również do aspektu energetycznego funkcjonowania państwa (m.in. prywatyzacja sektora naftowego, działania na rzecz zróżnicowania kierunków i źródeł dostaw surowców energetycznych).

\footnotetext{
${ }^{12}$ Do zagadnień, które nie powinny stanowić przedmiotu badań nad myślą polityczną w zakresie bezpieczeństwa energetycznego, można zaliczyć: 1) lokalizacja i wielkość zasobów surowców energetycznych; 2) wielkość wydobycia surowców energetycznych (ropa naftowa, gaz ziemny, węgiel kamienny i brunatny); 3) wielkość zainstalowanych mocy wytwórczych (elektrownie); 4) stan techniczny infrastruktury energetycznej (rurociągi, magazyny, terminale, elektrownie); 5) lokalizacja infrastruktury energetycznej; 6) stopień rozwoju i przepustowości krajowych oraz międzynarodowych połączeń systemowych (rurociągi, gazociągi, linie elektroenergetyczne); 7) eksploatacja urządzeń energetycznych.

13 Przykładem prac naukowych dotyczących bezpieczeństwa energetycznego Polski, w których autorzy analizują to zagadnienie przez opis aktywności politycznej mogą być następujące publikacje: J. Świątkowska, Bezpieczeństwo energetyczne jako fundament wspótczesnego bezpieczeństwa narodowego Polski, „Annales Universitatis Paedagogicae Cracoviensis. Studia Politologica" VIII/119 (2012), s. 154-175; D. Grala, Bezpieczeństwo energetyczne Polski na przełomie XX $i$ XXI wieku w aspekcie dostaw surowców z obszaru postradzieckiego, „Sprawy Wschodnie" 14-15/1-2 (2007), s. 3-18; A. Makowski, K. Kubiak, Znaczenie kierunku morskiego w dywersyfikacji dostaw gazu zimnego a bezpieczeństwo surowcowe kraju, [w:] Wspótczesne wyzwania bezpieczeństwa europejskiego, red. P. Mickiewicz, K. Kubiak, Pelpin 2004, s. 26-32.
} 
Uwzględniając istotę badań nad myślą polityczną, przedmiotem badań powinny być wszelkie poglądy i działania w sferze bezpieczeństwa energetycznego, które mają charakter politycznych (konfliktowy). W efekcie można wyodrębnić zagadnienia, stanowiące przedmiot badań myśli politycznej w zakresie bezpieczeństwa energetycznego państwa. Jednocześnie należy podkreślić, że zaproponowane zagadnienia mają zarówno charakter wewnętrzny (krajowy), jak i zewnętrzny (międzynarodowy). W tym kontekście dla przykładu można wskazać, że eksploatacja krajowych złóż surowców energetycznych, jak i realizowane projekty energetyczne wpływają na aktywność państwa w środowisku międzynarodowym, ponieważ warunkują kierunek i charakter prowadzonych działań (np. wydobycie krajowych złóż gazu ziemnego może zmniejszyć wielkość importu tego surowca). Jednocześnie aktywność innych państw determinuje dynamikę działań krajowych decydentów (np. wykorzystywanie przez eksporterów surowców energetycznych do realizacji celów polityki zagranicznej może wpłynąć na budowę alternatywnych systemów przesyłowych). W efekcie inna jest rola państwa oraz decydentów politycznych w analizowanych zagadnieniach (inicjator, uczestnik).

Do zakresu rzeczowego badań nad myślą polityczną w zakresie bezpieczeństwa energetycznego zaliczono dziewięć zagadnień. Po pierwsze - procesy gospodarcze, w tym kwestia własności w sektorach energetycznych. Proces przekształceń własnościowych w istotny sposób wpływa na poziom bezpieczeństwa energetycznego państwa. Sprzedaż mienia publicznego może docelowo skutkować ograniczeniem pozycji państwa w gospodarce. W tym kontekście różnica poglądów podmiotów politycznych na kwestię własności jest jednym z bardziej doniosłych problemów politycznych. Dlatego też przedmiotem badań myśli politycznej powinny być motywy oraz skutki (korzyści i zagrożenia) prywatyzacji dla funkcjonowania strategicznych gałęzi gospodarki (np. sektor naftowy, gazowy, węglowy, elektroenergetyczny).

Po drugie - koncepcje gospodarcze, w których zawarta jest wizja pożądanej struktury sektorów gospodarczych. Aktywna rola państwa w gospodarce może wpływać na kształt organizacyjny poszczególnych sektorów energetycznych. Prezentowane poglądy oraz podejmowane decyzje polityczne mogą znacząco zaważyć na warunkach prowadzenia działalności gospodarczej w państwie. W tym kontekście formułowane przez podmioty polityczne projekty rozwiązań o charakterze systemowym powinny być przedmiotem badań myśli politycznej.

Po trzecie - realizacja projektów o charakterze krajowym, jak i międzynarodowym zwiększających bezpieczeństwo energetyczne państwa. Podstawowym sposobem zapewnienia bezpieczeństwa państwa w aspekcie energetycznym w wypadku ograniczonych zasobów surowców energetycznych jest budowa krajowej infrastruktury oraz współpraca międzynarodowa. Stanowisko podmiotów politycznych wobec realizacji konkretnych przedsięwzięć może się istotnie różnić ze względu na rozbieżne koncepcje energetyczne. W tym kontekście poglądy podmiotów politycznych na budowę infrastruktury o charakterze krajowym (np. terminal regazyfikacyjny) oraz międzynarodowym (np. rurociąg Odessa-Brody-Płock) powinna być przedmiotem badań myśli politycznej.

Po czwarte - stosunek do krajowych złóż surowców energetycznych. Można wyróżnić dwa generalne sposoby zapewnienia bezpieczeństwa energetycznego państwa. Zgodnie z pierwszym podejściem państwo wykorzystuje własne udokumentowane i zdolne do wydobycia zasoby surowców energetycznych (samowystarczalność energetyczna). 
Zgodnie z drugim sposobem rządy dążą do utworzenia struktury dostaw, zróżnicowanej pod względem źródeł i tras importu (dywersyfikacja). W efekcie można wskazać, że eksploatacja krajowych zasobów surowców energetycznych w istotny sposób decyduje o poziomie bezpieczeństwa państwa. Dlatego też analiza poglądów podmiotów politycznych na tego typu zagadnienia powinna stanowić jeden z elementów badań myśli politycznej.

Po piąte - akcesja do organizacji międzynarodowych o charakterze energetycznym. Zapewnienie bezpieczeństwa energetycznego polega między innymi na współpracy państw nie tylko w formie dwustronnej, ale również wielostronnej. Przystąpienie państwa do organizacji międzynarodowej wymaga spełnienia warunków określonych w wielostronnej umowie międzynarodowej, podjęcia decyzji politycznej oraz w niektórych przypadkach również akceptacji społeczeństwa (np. akcesja Polski do Unii Europejskiej). Prowadzenie badań nad myślą polityczną (analiza stanowiska podmiotów politycznych) w kontekście członkostwa państw w organizacjach międzynarodowych o charakterze energetycznym powinna być przedmiotem zainteresowania badaczy ze względu na polityczność tego problemu.

Po szóste - ekspansja kapitałowa przedsiębiorstw energetycznych. Zaangażowanie finansowe spółek energetycznych poza granicami państwa z oczywistych względów nie zawsze będzie stanowić przedmiot badań myśli politycznej. W tym kontekście należy wskazać, że jedynie taka aktywność biznesowa, jak zakup licencji wydobywczych lub aktywów poza granicami państwa, powinna być przedmiotem analiz politologicznych ze względu na różnorodność postaw podmiotów politycznych wobec tego typu działalności. W efekcie jedynie zaangażowanie przedsiębiorstw w projekty (np. zakup w 2006 r. spółki AB Mažeikiu Nafta przez PKN ORLEN S.A.), które docelowo mogą zwiększyć bezpieczeństwo energetyczne państwa, powinno stanowić przedmiot zainteresowań badaczy myśli politycznej.

Po siódme - stosunek do inwestycji międzynarodowych mogących negatywnie wpłynąć na bezpieczeństwo energetyczne państwa. Realizowane w środowisku międzynarodowym projekty energetyczne oddziałują na państwa, stanowiąc niekiedy zagrożenie dla ich bezpieczeństwa. W efekcie podmioty polityczne, ze względu na występujące impulsy ze strony innych państw (powodujące zmianę otoczenia zewnętrznego), wymuszają potrzebę dokonania oceny oraz skutków konkretnych projektów na bezpieczeństwo energetyczne danego państwa. W tym aspekcie formułowane przez podmioty polityczne poglądy mogą się zdecydowanie różnić i dlatego też powinny być przedmiotem badań myśli politycznej ${ }^{14}$.

Po ósme - projekty polityczne dotyczące zapewnienia bezpieczeństwa energetycznego państwa. Zagwarantowanie bezpieczeństwa energetycznego państwa wiąże się między innymi $\mathrm{z}$ aktywnością decydentów politycznych, w tym formułowanych przez nich projektów o charakterze międzynarodowym. Jedną z form współpracy międzynarodowej pomiędzy państwami są organizacje międzynarodowe. W tym kontekście prezentowane

14 Przykładem projektu energetycznego mogącego stanowić zagrożenie dla bezpieczeństwa energetycznego państwa jest Gazociąg Północny, prowadzący ze złóż gazu ziemnego w Federacji Rosyjskiej, a odbiór tego surowca jest w Republice Federalnej Niemiec. M. Rydel, Partie polityczne w Polsce wobec projektu budowy Gazociąu Pólnocnego, [w:] Relacje nowych krajów Unii Europejskiej z Federacją Rosyjska (w basenie Morza Bałtyckiego), red. M. Rutkowski, Białystok 2009, s. 483-494. 
przez podmioty polityczne koncepcje służące realizacji określonych zadań pomiędzy państwami (zapewnienie bezpieczeństwa energetycznego) powinny stanowić jeden $\mathrm{z}$ obszarów badań myśli politycznej ${ }^{15}$.

Po dziewiąte - współpraca energetyczna z konkretnymi państwami oraz ocena tej kooperacji. Ograniczone zasoby surowców energetycznych wymuszają potrzebę importu niezbędnych do funkcjonowania gospodarki nośników energii. W tego typu sytuacji stosunki dwustronne pomiędzy państwami w istotny sposób wpływają na poziom bezpieczeństwa energetycznego państwa. Poglądy podmiotów politycznych na kooperację z poszczególnymi partnerami międzynarodowymi mogą się różnić w sposób zasadniczy (np. stosunek Prawa i Sprawiedliwości i Sojuszu Lewicy Demokratycznej wobec współpracy z Federacją Rosyjską). W tym kontekście przedmiotem badań myśli politycznej powinny być przesłanki, które decydują o realizowanej kooperacji dwustronnej w aspekcie energetycznym i jej ocena, a nie jedynie sam opis tej współpracy.

Uogólniając, należy stwierdzić, że poglądy podmiotów politycznych na kwestię zapewnienia bezpieczeństwa energetycznego powinny być przedmiotem badań politologicznych. Zjawiska i wydarzenia o charakterze ekonomicznym istotnie determinują bezpieczeństwo państwa. Dlatego też tego typu problematyka jest kluczowa, ponieważ uzależnienie energetyczne (podległość o charakterze energetycznym) decyduje o kierunku i rozwoju państw.

\section{UWAGI KOŃCOWE}

Współcześnie bezpieczeństwo energetyczne państwa jest z jednej strony niezwykle ważnym zagadnieniem naukowym, $\mathrm{z}$ drugiej zaś stanowi rzeczywiste wyzwanie dla decydentów. Znaczenie tego zagadnienia jest uwarunkowane czynnikami o charakterze wewnętrznym (rozwój krajowych systemów energetycznych), jak i zewnętrznym (oddziaływanie na impulsy ze strony innych państw). Wszelkie zmiany w gospodarce krajowej oraz w otoczeniu międzynarodowym skutkują reorientacją zdolności państw do działań i oddziaływań. Jednocześnie należy wskazać, że wykorzystywanie przez poszczególne rządy do celów politycznych (realizowanej polityki zagranicznej) surowców energetycznych stanowi istotne uzasadnienie prowadzenia badań nad bezpieczeństwem energetycznym państw.

Podejmując badania nad myślą polityczną w zakresie bezpieczeństwa energetycznego, niezwykle istotne jest precyzyjne określenie sposobu rozumienia terminu „,bezpieczeństwo energetyczne” w odniesieniu do dwóch współcześnie dominujących nurtów badawczych (liberalizm, realizm). Tylko wtedy będzie możliwe dokonanie oceny

\footnotetext{
15 W latach 2006-2014 na forum międzynarodowym sprawujące w Polsce rządy formułowały koncepcje zapewnienia bezpieczeństwa energetycznego państwa. W 2006 r. w wyniku rosyjskoukraińskiego kryzysu gazowego z przełomu 2005/2006 rząd Kazimierza Marcinkiewicza zaproponował powołanie organizacji międzynarodowej (projekt Europejskiego Traktatu Bezpieczeństwa Energetycznego). Następnie w 2014 r. w wyniku konfliktu rosyjsko-ukraińskiego rząd Donalda Tuska zaproponował rozszerzenie zakresu przedmiotowego zagadnień regulowanych na forum Unii Europejskiej (projekt Unii Energetycznej). Na temat projektu Europejskiego Traktatu Bezpieczeństwa Energetycznego zob. M. Paszkowski, Projekt Europejskiego Traktatu Bezpieczeństwa Energetycznego w myśli politycznej Prawa i Sprawiedliwości, [w:] Polityka Polska w Europie. Tradycje, współczesność, wyzwania przyszłości, red. A. Laska, Rzeszów 2013, s. 87100.
} 
formułowanej przez poszczególne podmioty polityczne polityki energetycznej. Na podstawie przyjętych kryteriów można następnie przeprowadzić badania nad myślą polityczną, w odniesieniu do konkretnych zagadnień i wydarzeń o charakterze energetycznym, które w danym czasie uznawane są za polityczne (konfliktowe). Należy zatem wskazać, że brak jednoznacznego zdefiniowana terminu „bezpieczeństwo energetyczne" (przyjętego na potrzeby badań naukowych) będzie skutkować różną oceną formułowanych poglądów, a w konsekwencji - rzeczywistych działań podejmowanych przez poszczególne podmioty polityczne.

Podsumowując, zaproponowany zakres rzeczowy badań nad myślą polityczną w odniesieniu do bezpieczeństwa energetycznego państwa nie ma zamkniętego charakteru. Niemniej jednak formułując konkretne zagadnienia oraz wydarzenia energetyczne, które powinny być przedmiotem badań w zakresie myśli politycznej, należy brać pod uwagę ich konfliktowy charakter. Należy jednak wskazać, że w prowadzeniu badań naukowych nad myślą polityczną w wymiarze energetycznym niezbędne jest określenie istoty sporów, powstałych między podmiotami politycznymi (m.in. politycy, ugrupowania polityczne), dotyczących programów, koncepcji i strategii zapewnienia bezpieczeństwa energetycznego państwa.

\section{LITERATURA}

[1] Burchill S., Liberalizm, [w:] Teorie stosunków międzynarodowych, red. S. Burchill i in., Warszawa 2006.

[2] Burchill S., Realizm i neoliberalizm, [w:] Teorie stosunków międzynarodowych, red. S. Burchill i in., Warszawa 2006.

[3] Buzan B., People, States and Fear. An Agenda for International Security Studies in the Post-cold War Era, London 1991.

[4] Czaputowicz J., Bezpieczeństwo w teoriach stosunków międzynarodowych, [w:] Bezpieczeństwo międzynarodowe. Przegląd aktualnego stanu, red. K. Żukrowska, Warszawa 2011.

[5] Czaputowicz J., Teorie stosunków międzynarodowych. Krytyka i systematyzacja, Warszawa 2007.

[6] Dziennik Ustaw 1997, nr 54, poz. 348, ze zm., Ustawa z 10 kwietnia 1997 roku Prawo energetyczne.

[7] Grala D., Bezpieczeństwo energetyczne Polski na przełomie XX i XXI wieku w aspekcie dostaw surowców z obszaru postradzieckiego, „Sprawy Wschodnie” 14-15/ 1-2 (2007).

[8] Jackson R., Sørensen G., Wprowadzanie do stosunków międzynarodowych. Teorie i kierunki badawcze, Kraków 2006.

[9] Kuźniar R., Bezpieczeństwo w stosunkach międzynarodowych, [w:] Stosunki międzynarodowe. Geneza - Struktura - Dynamika, red. E. Haliżak, R. Kuźniar, Warszawa 2006.

[10]Makowski A., Kubiak K., Znaczenie kierunku morskiego w dywersyfikacji dostaw gazu zimnego a bezpieczeństwo surowcowe kraju, [w:] Współczesne wyzwania bezpieczeństwa europejskiego, red. P. Mickiewicz, K. Kubiak, Pelpin 2004.

[11]Paruch W., Kategorie ekonomiczne a zakres pojęcia myśl polityczna - refleksje metodologiczne, [w:] Idee, państwo, ludowcy. Księga jubileuszowa z okazji 70. 
rocznicy urodzin profesora Jana Jachymka, red. E. Maj, S. Michałowski, A. Wójcik, Lublin 2009.

[12]Paszkowski M., Projekt Europejskiego Traktatu Bezpieczeństwa Energetycznego w myśli politycznej Prawa $i$ Sprawiedliwości, [w:] Polityka Polska w Europie. Tradycje, współczesność, wyzwania przyszłości, red. A. Laska, Rzeszów 2013, s. 87-100.

[13]Rydel M., Partie polityczne w Polsce wobec projektu budowy Gazociagu Pólnocnego, [w:] Relacje nowych krajów Unii Europejskiej z Federacją Rosyjska (w basenie Morza Battyckiego), red. M. Rutkowski, Białystok 2009.

[14] Stańczyk J., Współczesne pojmowanie bezpieczeństwa, Warszawa 1996.

[15] Symonides J., Kategoria bezpieczeństwa $w$ nauce o stosunkach międzynarodowych, [w:] Bezpieczeństwo narodowe i międzynarodowe u schyłku XX wieku, red. D. B. Bobrow, E. Haliżak, R. Zięba, Warszawa 1997.

[16] Symonides J., Pojęcie $i$ istota bezpieczeństwa państwa $w$ stosunkach międzynarodowych, ,Sprawy Międzynarodowe” 1989/10.

[17] Symonides J., Pozimnowojenny paradygmat bezpieczeństwa międzynarodowego, [w:] Bezpieczeństwo międzynarodowe po zimnej wojnie, red. R. Zięba, Warszawa 2008.

[18] Symonides J., Problem pokoju i bezpieczeństwa międzynarodowego we współczesnym świecie, [w:] Wychowanie dla pokoju, red. B. Suchodolski, Wrocław-Warszawa-Kraków-Gdańsk-Lódź 1983.

[19] Świątkowska J., Bezpieczeństwo energetyczne jako fundament współczesnego bezpieczeństwa narodowego Polski, „Annales Universitatis Paedagogicae Cracoviensis. Studia Politologica” VIII/119 (2012).

[20] Zięba R., Cele polityki zagranicznej państwa, [w:] Wstęp do teorii polityki zagranicznej państwa, red. R. Zięba, Torun 2004.

[21] Żukrowska K., Pojęcie bezpieczeństwa i jego ewolucja, [w:] Bezpieczeństwo międzynarodowe. Teoria i praktyka, red. M. Grącik, K. Żukrowska, Warszawa 2006.

\section{SPECIAL FEATURES OF REASERCH ON POLITICAL THOUGHT IN THE FIELD OF ENERGY SECURITY}

Security is one of the most important tasks of policy-makers of each country. The importance of this issue is determined by factors of an internal nature (development of national energy systems) and external (impulses from other countries). Recently, due to the evolution of the international environment, non-military aspects of security are becoming more important. The aim of the article was to determine the essence of political science research on political thought in the field of energy security. This issue is an important category of research that was previously analyzed in a negligible extent. The article presents a way of defining the term energy security by supporters of the two dominant contemporary paradigms in international relations (realism, liberalism). In the article author proposed nine processes and events that should be the subject of research scientists who are analyzing political thought in terms of energy security. First - economic processes, including the question of ownership in the energy sectors. Second - economic concepts, which is a vision of the desired structure of economic sectors. Third - the implementation of projects on a national and international level to enhance the energy security. Fourth - attitude to the development of domestic energy resources. Fifth - accession to international energy organizations. Sixth - capital expansion of national energy companies. Seventh - attitude 
towards international investment which could affect the energy security of the state. Eighth - political projects ensuring energy security. Ninth - energy cooperation with specific countries and an assessment of the cooperation.

Keywords: realism, liberalism, political thought, energy security.

DOI:10.7862/rz.2015.hss.22

Przesłano do redakcji: listopad 2014

Przyjęto do druku: wrzesień 2015 